Editorial

\title{
Dimethyl Ether (DME) - Potential Biofuel in Malaysia
}

\section{Editorial}

Dimethyl ether (DME), with a chemical formula of $\mathrm{C}_{2} \mathrm{H}_{6} \mathrm{O}$, is a nontoxic, clean burning and potentially renewable fuel. It has high value of cetane number and quiet combustion thus makes it an excellent substitute of diesel fuel that will meet strict emissions standards.DME can be derived from many renewable materials such as biomass, agricultural products, waste and fossil fuels, which included natural gas and coal. ${ }^{1}$ Through a variety of feedstock namely coal, natural gas or biomass, DME can be produced together with by-products such as hydrogen and methanol. ${ }^{1}$ Nevertheless, biomass is believed to be one of the most sustainable ways to reduce the impact of the reduction of energy sources and environmental issue.

DME has been used in many countries for decades as an energy source. Country such as Japan, China, Korea, and Brazil are using DME due to it has remarkable potential for automotive fuel, power generation, and domestic application like cooking and heating, which can replace the LPG (liquefied petroleum gas). It is a gas under ambient conditions with properties similar to those of propane. However, it can be stored as liquid under moderate pressure and easier to transport. ${ }^{2}$ Due to its chemical properties to become liquid phase at moderate pressure, it can eliminate the need for the high pressure containers used for storage such as the storage of LNG (liquefied natural gas).

The idea of launching DME as biofuel in transportation, agriculture and construction industries is a wise decision. The cost of production would not be affected upon the price of crude oil. Next, there is numerous advantage of using DME over a diesel fuel. First, it could improve the engine performance. DME compression ignites in a diesel engine without the use of spark plugs, increasing engine efficiency and resulting in diesel-like power and torque. Due to the cleaning burning properties of DME, no diesel particulate filter (DPF) is required, thus it can reduce the after-treatment equipment and associated maintenance. Amongst others the Volvo group is performing extensive research into the use of DME as a fuel for busses and trucks. ${ }^{3}$

Furthermore, DME is a famous cosmetic propellant, propane replacement, fuel-cell fuel, gas turbine fuel and coolant for refrigeration system. Other than that, DME emerges as one of the alternative clean fuels for diesel engines due to its high engine performance and low emission of $\mathrm{CO}, \mathrm{NO}_{x}$ and particulates during combustion. There are some trucks company using DME as additive that blended with gasoline to improve engine performance under enforcement of the use of bio-fuel. A share of $10 \%$ biofuels for 2020 is set by the European Union to impose the use of biomass derived transportation fuels. ${ }^{1}$ As a summary, DME has a potential diesel fuel and propane fuel blending agent. It has shown its captivity as a second generation and renewable energy source.

World's first plant for the production of DME is being built by Chemrec, which is the Sweden Corporation with headquarter is located in Stockholm, Sweden. ${ }^{4}$ It develops technology for entrained flow gasification of black liquor for the production of biofuel. Black liquor is an aqueous solution of lignin residues, hemicelluloses and recoverable inorganic chemicals used in the Kraft pulping process. Today, black liquor is the most important source of energy from biomass in countries such as Sweden and Finland with a large pulp and paper industry. The black liquor is gasified and the synthesis gas can
Volume I Issue I - 2016

\author{
Po Kim Lo \\ Faculty of Engineering \& Green Technology, UniversityTunku \\ Abdul Rahman, Malaysia
}

Correspondence: Po Kim, Lo, Faculty of Engineering \& Green Technology, University Tunku Abdul Rahman, Malaysia, Email lopk@utar.edu.m

Received: August 08, 2016| Published: August 18,2016

be used to produce methanol and/or dimethyl ether (DME). Basically the black liquor is sustainable because it is able to be maintained at a certain rate. In Malaysia, the biomass proposed to replace black liquor to produce DME is empty fruit bunch (EFB). EFB from oil palm is one of the potential biomass to produce biofuels such as DME due to its abundant supply and favourable physicochemical characteristics.

Besides, according to Transparency Market Research report for year 2015, the global dimethyl ether market and across the globe was valued at US\$4.46Bn in 2013 and is like to reach US\$8.37 Bn in 2020 expanding at a CAGR of $9.4 \%$ between 2014 and 2020. This statement can be supported by the targeted production of methanol, dimethyl ether, olefin and oil in 2010, 2015 and 2020 reported by National Development and Reform Commission, showing a rapidly increase in production of DME from 3 million tons in 2010 to 11 million tons in 2015 .

Moreover, in 2013, Malaysia government has introduced a range of policies to improve the energy security. Malaysian energy policy was giving attention on the use of oil and gas but a policy on Renewable Energy was introduced in year 2001 to search alternatives to existing energy sources. The government has sought to promote the manufacture of biofuel derived from palm-oil to capitalize on the growing international demand for biofuels, seen as an alternative to fossil fuels amidst concerns over rising fuel costs, greenhouse gas emissions and energy security. ${ }^{5}$ Malaysia has a good platform to develop biomass industry due to the availability of raw materials such as oil palm waste, sugar cane, paddy husk and wood-chip. Besides, in 2006, Malaysian government launched its National Biofuel Policy to promote commercialization, use export and research of biodiesel derived from palm oil. ${ }^{5}$ Thus, the government of Malaysia is very encouraged the research and development of the alternative fuels to improve the country economic and increase the name of nation. In support of the biofuel industry, the Malaysian government reportedly allocated about US $\$ 26.8$ million in the form of low-interest loans and federal grants for research and development and demonstration projects, between 2004 and $2006 .{ }^{6}$ As incentives to biodiesel manufacturers, biodiesel processing projects are eligible for pioneer status or the Investment Tax Allowance (ITA) under the Promotion of Investments Act 1986. Perhaps the same incentives could be provided to DME manufacturer as well.

Finally, as the alternative fuel, DME is environmental friendly, it is not harmful to ozone layer, it does not form explosive peroxides, it has high $\mathrm{CN}$ and it is an outstanding substitute to the present transportation fuel. ${ }^{7}$ Production of DME is still new in Malaysia and it will be more 
attractive and gain more attention from the industries and Malaysia government in coming future.

\section{Acknowledgements}

The authors would like to thank Mr.Lee HorngYih and his team for their contribution and Department of Petrochemical Engineering, Faculty of Engineering and Green Technology, Universiti Tunku Abdul Rahman, Malaysia.

\section{Conflict of interest}

Authors declare there is no conflict of interest in publishing the article.

\section{References}

1 Azizi Z, Rezaeimanesh M, Tohidian T, et al. A review of technologies and production challenges. Chem Eng and Proc: Process. 8:150172.
2 McKone T, Rice D, Ginn T, et al. California dimethyl ether multimedia evaluation. The University of California, Berkeley, USA; 2015: 1-164.

3 Johansson L. Climate issues in Focus: volvo group. Sweden; 2014.

4 Yan J. Handbook of clean energy system. Wiley\& Sons Ltd. USA, 2015;6:179.

5 Chin M. Biofuels in Malaysia: an analysis of the legal and institutional framework. Center for International Forestry Research. Indonesia; 2011.

6 Lopez G L, Laan T. Biofuels-at what cost: government support for biodiesel in Malaysia. International Institute for Sustainable Development. Canada; 2008.

7 Baskaran R. Analysis on synthesis, storage \& combustion: characteristics of DME as fuel in CI engines. Int $J$ Res AppSci Eng Tech. 2015;3(1):133-140. 